\title{
Assessment of Bacteriological Quality of Drinking Water in
}

\section{some Household Water Filter Systems in Benghazi City}

\author{
Abaza AF, Abbass $A A^{*}$, El Shamy $\mathrm{HA}^{*}$, Meidan $\mathrm{TM}^{* *}$, Elzouki $\mathrm{EM}^{* *}$
}

\begin{abstract}
Water is very important to human beings. Although human life can exist for many days without food, the absence of water for only a few days has fatal consequences. A wide variety of commercial water treatment systems are available for application to treat very small quantities, such as for individual homes or taps. These can treat virtually any water quality problem. It is important to have a good understanding of the specific water quality problems before selecting water treatment system. It is also important that products be tested and approved by a qualified independent certification organization to have confidence that the device will indeed perform as the vendor claims. The present study aimed to assess the bacteriological quality of drinking water in some household water filter systems in Benghazi city. The study was carried out on a total of 600 water samples (300 tap water samples and 300 filter water devices samples). All water samples were examined for enumeration of viable heterotrophic bacteria by pour plate method and enumeration of total coliforms (TC) by both the multiple tube fermentation (MTF) and membrane filtration (MF) methods and for thermotolerant coliforms (TTC), Fecal streptococci (FS), and Pseudomonas aeruginosa ( $P$. aeruginosa) by the MF method. According to Libyan guidelines, out of 600 examined drinking water samples $76.8 \%$ were acceptable. The highest percentage of acceptable samples was revealed from reverse osmosis $(\mathrm{RO})$ system $(90.7 \%)$, followed by charcoal filter $(83.3 \%)$, tap water distribution system (DS) $(82.3 \%)$, and only $54.7 \%$ from tap water tanks. It was concluded from this study that filtered water samples were found to be superior to tap water samples as regards their bacteriological aspects. In addition, $P$. aeruginosa was considered as an excellent indicator for the efficiency of the water filters.
\end{abstract}

\section{INTRODUCTION:}

The key to increase human productivity

and long life is good quality water.(1)

Drinking water is an important resource all

around the globe. (2) It is one of the most

important commodities which man has sustenance of his life. ${ }^{(3)}$

Outbreaks of waterborne infectious diseases via the use of contaminated drinking water still pose a serious health threat worldwide, despite the fact that drinking water is one of the most closely
Department, Alexandria University, Egypt.

${ }^{*}$ High Institute of Public Health, Microbiology Department, A
${ }^{*}$ Faculty of Medical Technology, University of Derna, Lybia 
monitored and strictly regulated resources.

Careful estimates indicate that each year about 350 million people are infected by waterborne pathogens, with 10 to 20 million succumbing due to severe cases of infection. (4) This phenomenon is far from being restricted to developing countries but also threatens developed countries. In the United States (US), almost 430,000 cases were reported in 126 outbreaks of waterborne infectious diseases during years from 2003 to 2005. ${ }^{(5)}$

The number of different types of pathogens that can be present in water as a result of contamination with human or animal feces is very large and it is not possible to test water samples for each specific pathogen. Therefore, scientists and public health officials typically choose to monitor non pathogenic bacteria that are usually associated with pathogens transmitted by fecal contamination; but are more easily sampled and measured. These associated bacteria are called indicator organisms. (6)

Aeromonas species and $P$. aeruginosa have been advocated as a means of monitoring the hygienic quality of drinking water. They indicate the general cleanliness of the distribution system and are used to assess the quality of filter water devices as their presence suggests non compliance with good manufacturing. ${ }^{(7,8)}$

A wide variety of commercial water treatment systems are available for application to treat very small quantities, such as for individual homes or taps. These can treat virtually any water quality problem. A major goal in water treatment is to produce clear, good tasting water. Adsorption has been used for many years to help achieve this goal by removing organics that cause taste, odor and color in drinking water. Recently it is also becoming an important method for protecting public health by removing toxic organic chemicals from drinking water. $(9,10)$

There are a number of methods 
available to improve or enhance drinking water quality. People work very hard to improve treatments like purification and disinfection and to get perfect product-drink safe for health and necessary for life called simply Household water filters (HHWFs). ${ }^{(11,12)}$

Water filters have been introduced for many centuries; they are closely related to the history of water. Various filtration methods for reducing microbes in water have been widely known and practiced for decades. ${ }^{(13)}$

According to the history of water treatment the use of water filters began more than 4000 years ago. As early as 1500 years ago, Egyptians recommended the application of coagulant alum to settle out the suspended solids from water. (14)

Household water management practices have been introduced in approximately 50 developing countries. These range from simple filters made from sari cloth and nylon to commercially produced sachets of flocculantdisinfectants. ${ }^{(15)}$

Geldreich et. al., (16) reported that, installation and use by the public of in-thehome, point of use (POU) water treatment devices have increased during the last several years. This trend has paralleled increased consumer awareness of the potential health risks posed by some community drinking water systems.

Although filtration was recognized for removal of undesirable particles and microbes, several studies showed high bacterial counts in fresh filtered than in tap water after approximately one week of use. $(17,18,19)$

For this reason, the assessment of the biological characteristics of filtered and tap water is of great significance.

\section{Aim of the Work:}

The present study aimed to assess the bacteriological quality of drinking water in some household water filter systems in Benghazi city. 


\section{Material \& Methods:}

The study was carried out during 11 months, from the beginning of March 2008 till the end of January 2009, on a total of 600 water samples (300 tap water samples and 300 filter water devices samples). These samples were collected monthly.

\section{Tap water samples:}

A total of 300 water samples were collected from 21 various areas in Benghazi city (130 samples from DS and 170 samples from tanks).

Filter water devices:

\section{1) Charcoal filter samples}

A total of 150 water samples were collected from 14 various areas in Benghazi city.

\section{2) RO filter system samples}

A total of 150 water samples were collected from 16 various areas in Benghazi city.

Water samples were aseptically collected in $500 \mathrm{ml}$ sterile bottles. These bottles contained sodium thiosulphate for all water samples.

The water samples were directly transferred to the laboratory and examined within 1-6 hours of collection. Each sample was vigorously shaken and subjected to bacteriological examination.

\section{1) Enumeration of heterotrophic plate count (HPC) using standard pour plate method.}

It was done using the standard pour plate method. Water samples were subjected to serial 10- fold dilutions using sterile peptone water, and one $\mathrm{ml}$ of each sample and / or the appropriate dilutions were dispensed into sterile glass Petri dishes. Duplicate petridishes for appropriate dilutions were inoculated. Then $15 \mathrm{ml}$ volumes of molten sterile plate count agar (PCA) tempered approximately to $45^{\circ} \mathrm{C}$ was aseptically poured into each plate. The agar was thoroughly mixed with the sample aliquots by gentle to and fro, clockwise and anticlockwise movements. The agar was allowed to set and solidify. The plates were 
then inverted and incubated at $37^{\circ} \mathrm{C}$ for 48

hours. The plates showing $30-300$ colonies

were counted using Quebec colony counter and expressed as cfu $/ \mathrm{ml}$ of the sample

\section{2) Enumeration of TC by MTF.}

\section{i. Presumptive phase}

Water sample volumes of 50 and $10 \mathrm{ml}$ were used .The $50 \mathrm{ml}$ volumes were inoculated into bottles containing $50 \mathrm{ml}$ double strength lauryl tryptose broth (LTB) and the $10 \mathrm{ml}$ volumes of water were inoculated into each of five replicate tubes each containing $10 \mathrm{ml}$ of double strength LTB.

All the inoculated bottles and tubes were shaken and incubated at $37^{\circ} \mathrm{C}$ for 24 48 hours. After 24 hours each tube and bottle was shaken gently and was examined for turbidity and/ or gas production. All bottles and tubes showing no gas or turbidity were re-incubated and re-examined at the end of 48 hours.

Production of growth and or gas in tubes or bottles within 48 hours was considered a positive result for presumptive test and was subjected to:

\section{ii . Confirmed Phase:}

Two loopfuls from each positive presumptive tube or bottle were inoculated into tubes each containing $5 \mathrm{ml}$ single strength Brilliant Green lactose bile broths (BGLBB). All tubes were shaken on a vortex mixer and incubated at $37^{\circ} \mathrm{C}$ for 48 hours. Tubes showing turbidity and gas production were considered positive for confirmed phase. The most probable number (MPN) of $\mathrm{TC} / 100 \mathrm{ml}$ of water sample was calculated from MaCradey probability tables.

3) Enumeration of TC, TTC, FS, $P$. aeruginosa by MF.

\section{Membrane filters}

Sterile cellulose acetate membrane filters of $0.45 \mathrm{um}$ pore size and $47 \mathrm{~mm}$ diameter were used.

\section{Filtration unit:}

The used filter holding assembly consisted of three glass funnels that fasten to three receptacles bearing porous plates to support 
the membrane filters. The parts of assembly were sterilized by autoclaving $121^{\circ} \mathrm{C} f$ or 20 minutes.

Procedures were performed according to the methods described by Eaton et al. ${ }^{(20)}$

Counting:

- Plates showing 20 to 80 coliform colonies not more than 200 colonies of all types per membrane were counted using Quebec colony counter.

- Both typical and atypical coliform colonies were counted.

- Typical TC colonies on m-Endo agar were pink to dark red in color with a green metallic sheen.

- Atypical coliform colonies on mEndo agar were dark red mucoid, or nucleated colonies without metallic sheen.

- The TC density was calculated by the following equation.

$$
\mathrm{TC} / 100 \mathrm{ml}=\frac{\text { Coliformcolonies counted }}{\text { mlof samplefiltered }} \times 100
$$

\section{Verification:}

Typical colonies and any atypical colonies were verified by picking at least 5 colonies from each plate and incubating them in LTB at $35^{\circ} \mathrm{C}$ for 48 hours and then in BGLBB at $35^{\circ} \mathrm{C}$ for 48 hours. Gas formed in LTB and confirmed in BGLBB within 48 hours verified the colony as a coliform.

For verified coliform counts, the initial count was adjusted based upon the positive verification percentage and was reported as "verified coliform counts/ 100ml."

Percentage verified coliforms $=$ Numberof verifiedcolonies

Totalno.of coliformscoloniessubjectedto verification $\mathrm{X} 100$

\section{3.a. Membrane Filtration Technique for} TTC:(20)

It was performed in a similar manner to that employed for enumeration of TC but by using m-FC agar plates. These plates were inverted and incubated at $35-37^{\circ} \mathrm{C}$ for 2 hours and then incubated at $44.5^{\circ} \mathrm{C}$ for 24 hours. 


\section{3.b.Membrane Filtration Technique for}

FS: ${ }^{(20)}$

It was performed in a similar manner to that employed for enumeration of TC but by using $\mathrm{m}-\mathrm{KF}$ agar plates. Plates were left for $30 \mathrm{~min}$, then inverted and incubated at $35^{\circ} \mathrm{C}$ for 48 hours.

\section{3.c. Membrane Filtration Technique for}

\section{P. aeruginosa: ${ }^{(20)}$}

It was performed in a similar manner to that employed for enumeration of TC but by using m-PA agar plates. Plates were left for $30 \mathrm{~min}$, then were inverted and incubated at $35^{\circ} \mathrm{C}$ for 48 hours.

\section{Results:}

According to WHO and Libyan guidelines, out of the 600 examined water samples $461(76.8 \%)$ were acceptable and 139(23.2\%) were unacceptable.

The results of this study can be summarized as follows:

1) Table (1) showed that the highest percentage of acceptable samples was revealed from RO system (90.7\%), followed by charcoal filter (83.3\%), tap water DS (82.3\%), and only $54.7 \%$ from tap water tanks.

2) Table (2) revealed that: a) The highest percentages of TC, TTC were isolated from tap water tanks (18.2\% and $4.1 \%)$ respectively, followed by tap water DS $(9.2 \%$ and $3.1 \%)$ respectively.

b) No FS were isolated from tap water or filter devices samples.

c) $P$. aeruginosa was isolated from filter water devices samples only (one sample from charcoal filter and three samples from RO filter system).

3) It is clear from tables (3), (4) \& (5) that:

a) The highest percentages of TC, TTC, $P$. aeruginosa and HPC were recorded from filter water devices samples of installment duration above 12 months.

b) No indicator organisms were revealed from water samples of RO filter systems installed for less than 12 months with the exception of only one unaccepted sample for TC. 
c) Water samples of charcoal filters installed for 12-18 months revealed indicator organisms as TC $13(17.3 \%)$, TTC $5(6.7 \%)$ and $P$. aeruginosa one (1.3\%).

4) Table (6) showed that the highest mean counts of HPC were revealed from tap water tanks (61.2 cfu/ml), followed by tap water DS (24.6 cfu/ml), charcoal filter (20.4 cfu/ml) and only (18.9 cfu/ml-) from RO system.

5) Table (7) revealed that TC were isolated from $\mathrm{RO}$ system and charcoal filter water samples when membranes were not changed according to manufacturer's instructions.

6) Table (8) demonstrated that $\mathrm{RO}$ system brand $A$ was the best brand as regards the bacteriological quality and its compliance with the Libyan standards for drinking water showing acceptable samples $98.2 \%$, followed by RO system brands B and C; (93.3\%) and $(80.0 \%)$ respectively.

7) It is apparent from table (9) that an agreement of $88.2 \%$ was found between both methods MF and MTF in detection of TC from the examined water samples.

\section{Discussion:}

The present study revealed that $23.2 \%$ of the 600 examined drinking water samples were bacteriologically unsatisfactory and were considered unacceptable as they failed to meet the Libyan guidelines. Nearly a similar percentage of $20 \%$ was reported by Brownell et al., (21) in Canada. Higher percentages were reported by Copeland et al.(22) in Brazil (30.3\%) ,Mahjoub et al.,(23) in Libya (30.4\%) , and Lamka et al.(24) in United States (35\%). A much lower percentage was reported by Essa ${ }^{(25)}$ in Egypt (3\%).

Household water treatment is a practical strategy to prevent waterborne diseases. (26) RO system and charcoal carbon are commonly used in Libya. (27) RO 
system in this study showed maximum reduction of microbial contamination and provided the highest percentage of acceptable water samples $(90.7 \%)$. Nearly a similar percentage was reported by Payment et al., (28) in United States (93\%). A lower percentage was reported by Miles et al., (18) in United States (73\%).

The charcoal filters generally improve the quality of household drinking water by removing objectionable tastes and odors as well as dirt, rust, and sand. (29) In this study, $83.3 \%$ of the 150 examined drinking water samples after charcoal filtration were bacteriologically satisfactory and met the Libyan guidelines. Johnston and Burt (30) reported nearly similar results for activated carbon (AC) filters (80.1\%).

Taylor et al (31) tested four POU carbon filter devices, installed in the cold water line, they found that these devices removed $60-80 \%$ of the influent chlorinated organic compounds when new filter cartridges were first put on line, but after 6-8 weeks, removal was reduced to < $10 \%$ as a result of decreased effectiveness of the filters.

Although coliform organisms may not always be directly related to the presence of fecal contamination or pathogens in drinking water, the coliform test is still useful for monitoring the microbial quality of drinking water. (32)

This study revealed that TC were isolated from $18.2 \%$ of examined tank water samples, this could suggest bacterial regrowth, decrease in free chlorine during storage or old tanks. Much higher percentages were reported by Chaidez et. al., (33) in United States (32\%), and Ojo et. al., (34) in Nigeria (40\%).

TTC were considered more faecal specific than TC, and their detection was used routinely. (35) This study showed that $4.1 \%$ of the examined drinking water samples yielded TTC from tanks. A much higher percentage was reported by Chaidez et. al., (36) in United States (20\%). 
In the present study the frequency of isolation of TC and TTC from RO systems were $(6.0 \%)$ and $(2.0 \%)$ respectively. Lechevallier et. al., (37) reported isolation rates of $(28.7 \%)$ and $(3.1 \%)$ for TC and TTC from granular activated carbon (GAC) filters respectively. This could be explained by the difficulty to maintain free residual chlorine in all parts of the filters.

Some outbreaks of gastrointestinal illness have been attributed to drinking water contaminated with $P$. aeruginosa. This organism is capable of growth in low substrate conditions and in the presence of high chlorine levels. (38) In the present study, $P$. aeruginosa was isolated from filter water devices morning samples (one sample from charcoal filter and three samples from RO filter system). This could be due to the fact that RO systems have plastic storage tanks which might help the colonization of bacteria and their resistance to disinfection: Another factor may be attributed to the membranes being unchanged as recommended by the manufacturers. Nearly a similar result was reported by Vonberg et al., (39) where only one water sample yielded $P$. aeruginosa after filtration.

Three different brands of household filter devices designated $\mathrm{A}, \mathrm{B}$ and $\mathrm{C}$ were examined in this study. It was found that RO system brand $A$ was the best brand as regards the bacteriological quality and its compliance with the Libyan standards for drinking water (98.2\%). It possessed the highest efficiency in purifying water, followed by RO system brand $\mathrm{B}$ and $\mathrm{C}$; $(93.3 \%)$ and $(80.0 \%)$ respectively, this could be due to accuracy, quality and efficiency of manufacturing parts of brand A. This was the same with the studied charcoal filters. In this present study, all the 55 water samples (100\%) from brand A RO filter system had HPC $<1 \mathrm{cfu} / \mathrm{ml}$. Nearly a similar percentage (95\%) was reported by Meckes et al., ${ }^{(40)}$ in Canada. In the present study as regards 
installment duration of filter devices and presence of indicator organisms in examined drinking water samples after filtration process, high percentages were recorded from filter water devices samples of installment duration above 12 months. It could be explained by the possibility that with prolonged duration the devices hypothetical durability and efficiency lessens. Another explanation may be that membranes were not changed according to country of origin or manufacturer's instructions time. Reasoner et al., (41) reported that microbial colonization of POU devices containing AC occurred after prolonged installation. It is apparent from core analyses that the PAC contained high densities of HPC bacteria after several months of use, suggesting that trapped organic materials within the activated carbon supported growth of heterotrophic bacteria.

MF is a useful technique for the majority of water quality laboratories as it is a relatively simple method to use. Many samples can be processed in a day with limited laboratory equipment by a technician with basic microbiological training. Nevertheless, since this method is not sufficiently specific, a confirmation stage is needed, which could take a further 24 hours after the first incubation period in selective media. (42) This present study showed that out of (600) examined tap water samples, 68(88.2\%) were positive for TC detection by MTF and MF methods and only $8(11.8 \%)$ were positive by MTF method and negative by MF method. An agreement of $93 \%$ was found between both methods in detection of TC.

\section{Conclusions:}

\section{It can be concluded from this study} that:

1. Filtered water samples were found to be superior to tap water samples as regards their bacteriological aspects.

2. The changing of the membranes of the filter devices according to the 
manufacturers instructions instructions as regards duration resulted in raised efficiency of filter and frequency.

devices where no indicator

B) To select a filter brand of high organisms were isolated from $\mathrm{RO}$ quality.

systems with changed membranes.

2- Guidelines of filtered water should be

3. P. aeruginosa is considered as an followed, considering the addition of $P$. excellent indicator for the efficiency aeruginosa as an indicator of filtered of the water filters. water quality.

\section{Recommendations:}

3- A further research is needed to

1- Using water filters improves its quality, with the following measures:

evaluate the extent and amount of carbon penetration through charcoal
A) To change filters' membranes according to manufacturer's filters and RO systems. 
Table (1): Results of the examined drinking water samples according to their source.

\begin{tabular}{|c|c|c|c|c|c|c|c|}
\hline \multirow{2}{*}{\multicolumn{2}{|c|}{ Water source }} & \multirow{2}{*}{$\begin{array}{l}\text { Number of } \\
\text { examined } \\
\text { samples }\end{array}$} & \multicolumn{2}{|c|}{$\begin{array}{l}\text { Acceptable } \\
\text { samples }\end{array}$} & \multicolumn{2}{|c|}{$\begin{array}{l}\text { Unacceptable } \\
\text { samples }\end{array}$} & \multirow[t]{2}{*}{$\chi^{2}(p)$} \\
\hline & & & No. & $\%$ & No. & $\%$ & \\
\hline \multirow[t]{2}{*}{ Tap water } & DS & 130 & 107 & 82.3 & 23 & 17.7 & \multirow{2}{*}{$\begin{array}{r}25.256 \\
(<0.001) \\
\end{array}$} \\
\hline & Tanks & 170 & 93 & 54.7 & 77 & 45.3 & \\
\hline \multirow[t]{2}{*}{$\begin{array}{l}\text { Filter water } \\
\text { devices }\end{array}$} & $\begin{array}{c}\text { Charcoal } \\
\text { filter }\end{array}$ & 150 & 125 & 83.3 & 25 & 16.7 & \multirow{2}{*}{$\begin{array}{c}73.433 \\
(<0.001)\end{array}$} \\
\hline & RO system & 150 & 136 & 90.7 & 14 & 9.3 & \\
\hline \multicolumn{2}{|c|}{ Total } & 600 & 461 & 76.8 & 139 & 23.2 & \\
\hline
\end{tabular}

Table (2): Frequency of isolation of the indicator organisms from the examined drinking water samples according to their source.

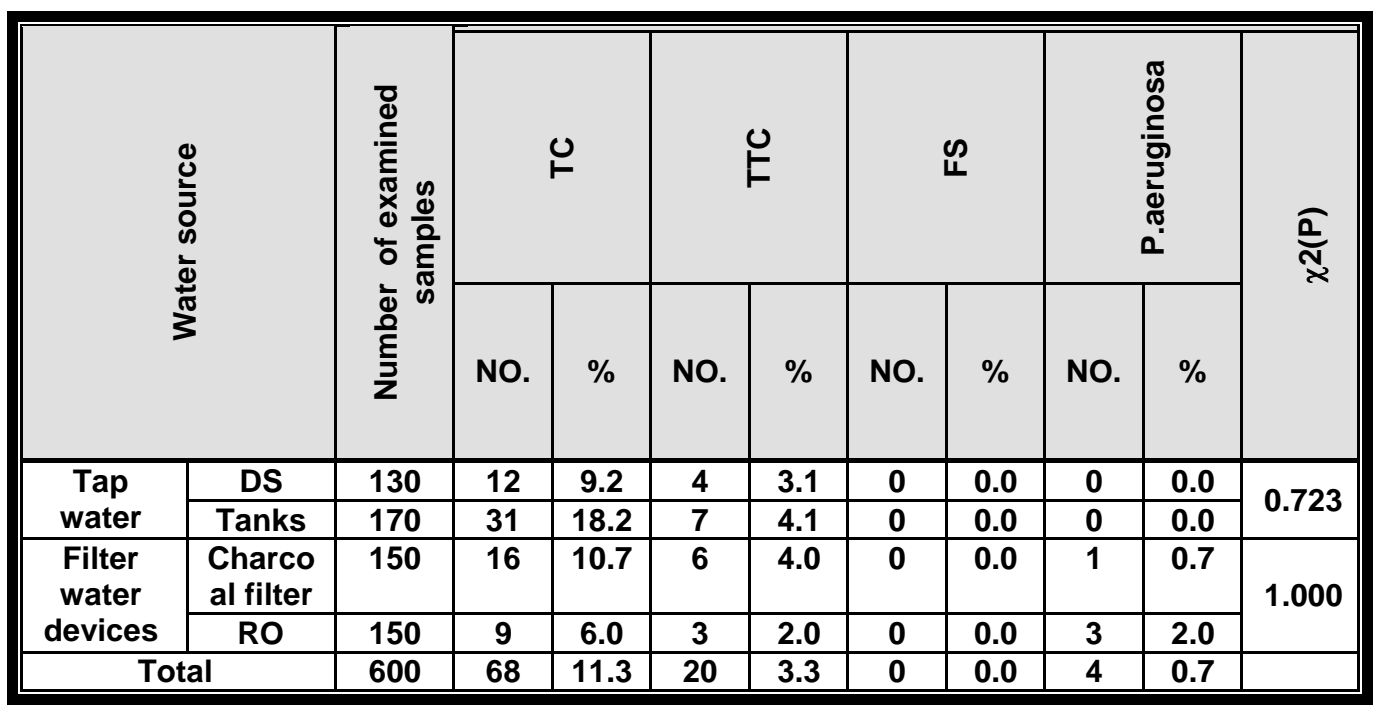


Table (3): Frequency of isolation of the indicator organisms from the examined drinking water samples according to the duration of installing the RO filter system devices.

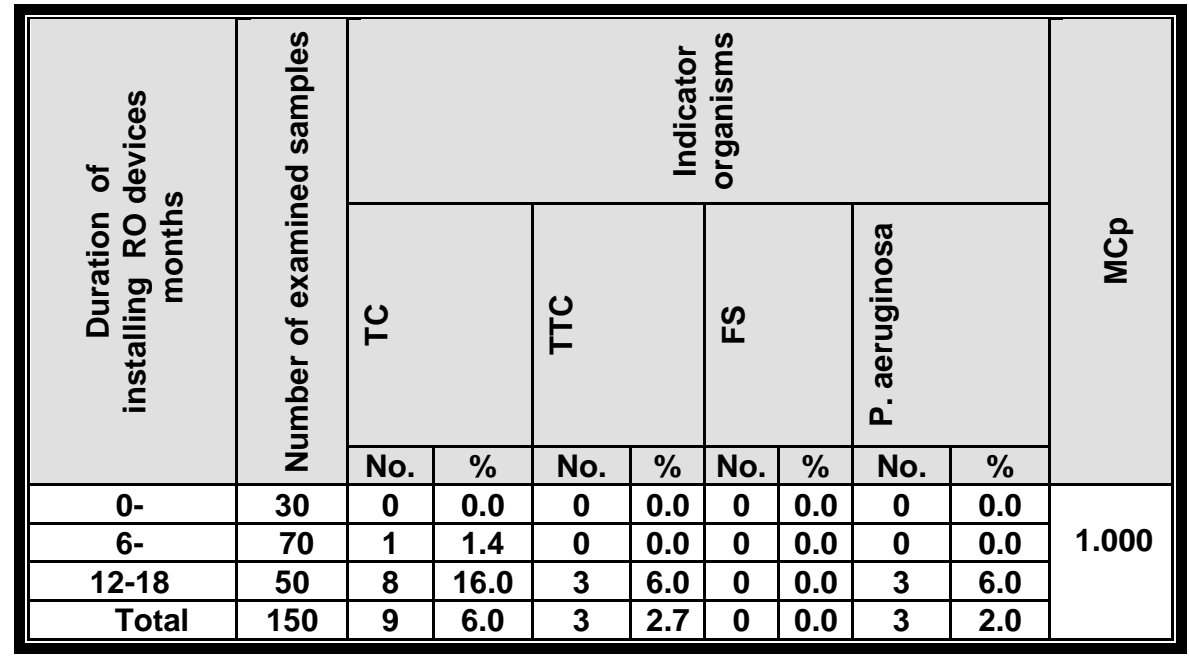

Table (4): Frequency of isolation of the indicator organisms from the examined drinking water samples according to the duration of installing the charcoal filter devices.

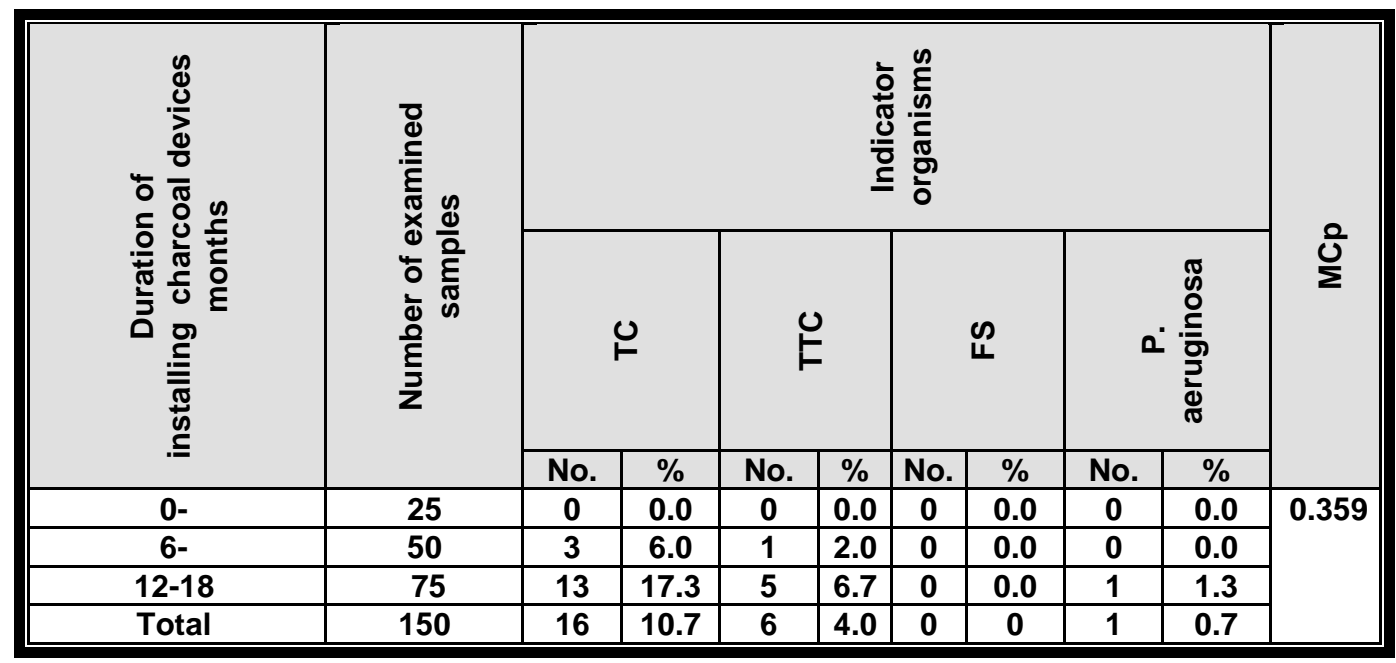


Table (5): Geometric mean counts of HPC of examined filter water devices samples according to the duration of installing the devices.

\begin{tabular}{|l|c|c|c|}
\hline $\begin{array}{l}\text { Duration of installing } \\
\text { the devices (months) }\end{array}$ & $\begin{array}{c}\text { Number of } \\
\text { examined samples } \\
(300)\end{array}$ & $\begin{array}{c}\text { HPC (cfu/ ml) } \\
\text { charcoal filter }\end{array}$ & $\begin{array}{c}\text { HPC (cfu/ ml) } \\
\text { RO }\end{array}$ \\
\cline { 2 - 4 } & 55 & Mean & Mean \\
\hline $0-$ & 120 & 1.1 & 2.04 \\
\hline $6-$ & 125 & 4.2 & 3.5 \\
\hline $12-18$ & & 15.1 & 13.4 \\
\hline F (p) ANOVA & 1.000 & 0.567 \\
\hline
\end{tabular}

Table (6): Geometric mean counts of HPC of examined water samples according to water source.

\begin{tabular}{|c|c|c|}
\hline \multicolumn{2}{|c|}{ Water source } & HPC (cfu ml) \\
\cline { 3 - 3 } & & Mean \\
\hline \multirow{2}{*}{ Tap water } & DS (130) & 24.6 \\
\cline { 2 - 3 } & Tanks (170 & 61.2 \\
\hline \multirow{2}{*}{ Filter water devices } & Charcoal filter (150) & 20.4 \\
\cline { 2 - 3 } & RO (150) & 18.9 \\
\hline \multicolumn{2}{|c|}{$F(p)$} & $5.957^{\star}(<0.001)$ \\
\hline
\end{tabular}

Table (7): Relation between frequency of isolation of indicator organisms from filter water samples and changing of the filter device membranes according to the manufacturers' instructions.

\begin{tabular}{|c|c|c|c|c|c|c|c|c|c|c|}
\hline \multirow{3}{*}{\multicolumn{2}{|c|}{$\begin{array}{l}\text { Change of the membrane } \\
\text { according to manufacturer's } \\
\text { instructions }\end{array}$}} & \multicolumn{8}{|c|}{ Indicator organisms } & \multirow[t]{3}{*}{$\chi^{2}(\mathrm{P})$} \\
\hline & & \multicolumn{2}{|c|}{ TC } & \multicolumn{2}{|c|}{ TTC } & \multicolumn{2}{|c|}{ FS } & \multicolumn{2}{|c|}{$\begin{array}{c}P . \\
\text { aeruginosa }\end{array}$} & \\
\hline & & No. & $\%$ & No. & $\%$ & No. & $\%$ & No. & $\%$ & \\
\hline \multirow[t]{2}{*}{ Charcoal filter (150) } & Yes* & 3 & 2.0 & 0 & 0.0 & 0 & 0.0 & 0 & 0.0 & \multirow[t]{5}{*}{$<0.001$} \\
\hline & No** & 13 & 8.6 & 6 & 4.0 & 0 & 0.0 & 1 & 0.7 & \\
\hline \multirow{2}{*}{$\begin{array}{l}\text { RO system } \\
(150)\end{array}$} & Yes & 0 & 0.0 & 0 & 0.0 & 0 & 0.0 & 0 & 0.0 & \\
\hline & No & 9 & 6.0 & 3 & 2.0 & 0 & 0.0 & 3 & 2.0 & \\
\hline \multicolumn{2}{|l|}{ Total } & 25 & 8.3 & 9 & 3.0 & 0 & 0.0 & 4 & 1.3 & \\
\hline
\end{tabular}

Yes*: change of membrane according to the manufacturer's instructions

No**: no change of membrane 
Table (8): Comparison between results of tap water and RO filter system water samples according to the filter brand.

\begin{tabular}{|c|c|c|c|c|c|c|c|c|c|c|c|}
\hline \multirow[b]{3}{*}{ Result } & \multirow{2}{*}{\multicolumn{2}{|c|}{$\begin{array}{c}\text { Tap water } \\
\text { (150) }\end{array}$}} & \multicolumn{8}{|c|}{ RO water devices (150) } & \multirow{4}{*}{$\begin{array}{l}27.985 \\
<0.001\end{array}$} \\
\hline & & & \multicolumn{2}{|c|}{$A(55)$} & \multicolumn{2}{|c|}{$B(45)$} & \multicolumn{2}{|c|}{$C(50)$} & \multicolumn{2}{|c|}{ Total } & \\
\hline & No. & $\%$ & No. & $\%$ & No. & $\%$ & No. & $\%$ & No. & $\%$ & \\
\hline Acceptable samples & 98 & 65.3 & 54 & 98.2 & 42 & 93.3 & 40 & 80.0 & 136 & 90.7 & \\
\hline $\begin{array}{l}\text { Unacceptable } \\
\text { samples }\end{array}$ & 52 & 34.7 & 1 & 1.8 & 3 & 6.7 & 10 & 20.0 & 14 & 9.3 & \\
\hline Total & 150 & 100 & 55 & 100 & 45 & 100 & 50 & 100 & 150 & 100 & \\
\hline
\end{tabular}

A: Made in United States

B: Made in Thailand

C: Made in China

Table (9): Comparative efficiency of MTF and MF in TC detection in examined tap water samples.

\begin{tabular}{|c|c|c|c|c|c|c|c||}
\hline \multirow{2}{*}{ TC by MF } & \multicolumn{2}{|c|}{ Positive } & \multicolumn{2}{|c|}{ Negative } & \multicolumn{2}{c|}{ Total } & \multirow{2}{*}{ Agreement } \\
TC by MTF & No. & $\%$ & No. & $\%$ & No. & $\%$ & $\%$ \\
\hline Positive & 60 & 88.2 & 0 & 0.0 & 60 & 88.2 & \multirow{2}{*}{$88.2 \%$} \\
\hline Negative & 8 & 11.8 & 0 & 0.0 & 8 & 11.8 & \\
\hline Total & 68 & 100 & 0 & 0.0 & 68 & 100 & \\
\hline
\end{tabular}


References:

1. Levy K, Nelson KL, Hubbard A, Eisenberg JN. Following the water: A controlled study of drinking water storage in Northern Coastal Ecuador. J Environ Health Perspectives. 2008; 116 (11):243-9.

2. Hammer MJ.Water and wastewater Technology. $6^{\text {th }}$ ed. India : Prentice-Hall inc; 2008.p.10.

3. Fewtrell L, Kaufmann R, Kay D, Enanoria W, Haller L, Colford J. Water sanitation, and hygiene interventions to reduce diarrhea in less developed countries. A systematic review and meta-analysis. Lancet Infect Dis. 2005;(5):42-52.

4. World Health Organization. Guidelines for Drinking Water Quality, First addendum to $2^{\text {nd }}$ ed. Health Criteria and Other Supporting Information. Geneva: WHO;1995.

5. World Health Organization. Guidelines for Drinking Water Quality, First addendum to $3^{\text {rd }}$ ed. Recommendations. Geneva: WHO; 2006.

6. Busta FF, Suslow TV, Parish ME, Beuchat LR, Farber JN, Garrett EH, et al. The use of indicators and surrogate microorganisms for the evaluation of pathogens in fresh and fresh-cut produce Comprehensive Rev Food Sci Food Safety. 2003; 2 (Suppl): S179-85.

7. Warburton DW, Harrison B, Crawford C, Foster R, Fox C, Gour L, et al. A further review of the microbiological quality of bottled water sold in Canada: 19921997 survey results. International J Food Microbiol .1998; 39: 221-6.

8. Warburton DW, Peterkin PI. Enumeration of Pseudomonas aeruginosa in prepackaged ice and water in sealed containers by hydrophobic grid- membrane filter (H6MF) technique. MFLP-61B. In: Compendium analytical methods. Vol 3.
Montreal: Polyscience Publications; 1993.

9. Brown J, Collin S, Suntura O, Clasen TF. Safe household water treatment and storage using ceramic drip filters. J Water Sci and Technol. 2004; 50(1):111-5.

10. Heinzel $E$, Hedrich $S$, Janneck B,Glombitza F, Seifert J, Schlömann M. Bacterial diversity in a nine water treatment plant. Appl Environ Microbiol. 2009;75(3):858-61.

11.Ngai TKK, Shrestha RR, Dangol B, Maharjan M,Murcott SA. Design for sustainable development-Household drinking water filter for arsenic and pathogen treatment in Nepal. J Environ Sci and Health Part A. 2007;42:187988

12. World Health Organization.Combating Waterborne Disease at the Household Level. Geneva: WHO; 2007.

13. Clasen TF, Garcia PG, Boisson S, Collin S. Household-based ceramic water filters for the prevention of diarrhea: a randomized, controlled trial of a pilot program in Colombia. J Am Trop Med Hyg. 2005;73(4):790-5.

14.Buffalo Water Authority managed by American water. History of Water Treatment.2000. Available from: http://www.buffalowaterauthority.com/histor yofwater\%20treatment.htm

15. Environmental Protection Agency. Draft Technical Guidance Manual for the Proposed Aircraft Drinking Water Rule (ADWR) .EPA,2008.

16. Geldreich EE, Taylor RH, Blannon JC, Reasner DJ. Bacterial colonization of Point of Use of water treatment devices. J Am Water Works Assoc. 1985;77(2):72-9.

17. Wright J, Gundry S, Conroy R. Household drinking water in developing countries: a systematic review of microbiological contamination between source and point-of-use. Trop Med \& International Health. 2004;9 (1):106-17. 
18. Miles SL, Gerba P, Pepper IL, Reynolds KA. Point-of-Use drinking water devices for assessing microbial contamination in finished water and distribution systems. J Environ Sci Technol .2009 Mar; 43(5):1425-9.

19. Fiore JV, Babineau RA. Effect of an activated carbon filter on the microbial quality of water. Appl Environ Microbiol. 1977; 34(5): 541-6.

20.Eaton AD, Cleseri LS, Rice EW,Greenberg AE. Standard Methods for the Examination of Water and Wastewater. 19 ${ }^{\text {th }}$ ed. Washington, DC: American Public Health Association (APHA); 2005.

21. Brownell SA, Chakrabarti AR, Kaser FM, Connelly LG, Peletz RL, Reygadas $\mathrm{F}$, et al. Assessment of a low cost pointof-use, ultraviolet water disinfection technology. J Water Health. 2008; (6):53-65.

22. Copeland CC, Beers BB, Thompson MR, Fitzgerald RP, Barrett LJ, Sevilleja JE et al. Faecal contamination of drinking water in a Brazilian shanty town: importance of household storage and new human faecal marker testing. J Water Health. 2009;7(2):324-31.

23. Mahjoub TM, Buazzi MM, Jamil AY. Contamination of Water Wells in Khoms City with Pathogenic Coliform Bacteria. J AL-Nawah. 2007;7(9):1-9.

24.Lamka KL, Lechevallier MMW, Seidler RJ. Bacterial Contamination of Drinking Water Supplies in a Modern Rural Neighborhood. Appl Environ Microbial 1980;39(4):734-39.

25. Essa OA. Coliphage and coliforms as indicators of fecal pollution in potable and nonpotable water in Alexandria.DPH, HIPH, Alexandria University; 2009.

26. Mintz ED, Reiff FM, Tauxe RV. Safe water treatment and storage in the home. A practical new strategy to prevent waterborne disease. J Am Med Assoc. 1995 Mar; 273(12):948-53.
27.A Guide to Water Filters and Water Treatment. (Homepage of internet). American: Free drinking water.com, 2005-2006. Available from: http://www.freedrinkingwater.com.

28. Payment P, Franco ER, Ichardson L, Siemiatycki J. Gastrointestinal Health Effects Associated with the Consumption of Drinking Water Produced by Point-of-Use Domestic Reverse-Osmosis Filtration Units. Appl Environ Microbiol.1991;57(4); 945-8.

29. Kohnena W, Keisera ST, Meyera HG, Loosb AH. Microbiological quality of carbonated drinking water produced with in-home carbonation systems. J Hygiene \& Environ Health.2005 Sept;208(5):415-23.

30. Johnston P, Burt SC. Bacterial growth in charcoal filters. J Appl Environ Microbiol.1979;13:240-5.

31. Taylor RH, Allen MJ, Geldreich EE. Testing of home use carbon filters. J Am Water Works Assoc. 1979 Oct; 71(10).

32.WHO. Guidelines for Drinking-water Quality. Vol 3. 2 nd ed. Surveillance and control of community supplies. Geneva: WHO; 1997.

33. Chaidez C, Ruiza C, Gerba ECP. Microbiological survey of private roof water tanks in Culiacan, Mexico. J Environ Sci \& health. 1999; 34(10):1967-78.

34. Ojo OA, Bakare SB, Babatunde AO. microbial and chemical analysis of potable water in public - water supply within Lagos university, Ojo Afr J Infect Dis. 2007;1(1):30 - 5 .

35.Wang DL, Fiessel W. Evaluation of media for simultaneous enumeration of total coliform and $E$. coli in drinking water supplies by membrane filtration techniques. J Environ Sci. 2008; 20(3):273-77.

36. United States Environmental Protection Agency (USEPA), Guidance manual for compliance with the interim enhanced 
surface water treatment rule-turbidity provisions: Office of Water, Washington, DC; 1999.

37.Lechevallier MW, Welch NJ, Smith DB. Full-Scale Studies of Factors Related to Coliform Regrowth in Drinking Water. Appl Environ Microbiol. 1996; 62(7):2201-11.

38. Verce MF, Ulrich RL, Freedman DL. Transition from Cometabolic to GrowthLinked Biodegradation of Vinyl Chloride by a Pseudomonas sp. Isolated on Ethene. J Environ Sci Technol. 2001;35 (21):4242-51.

39. Vonberg

RP, Rauchenberger

DR, Gastmeier P. Reusable terminal tap water filters for nosocomial legionellosis prevention. Annals of Hematology.2005 June;84 (6):403-6.
40.Meckes MC, Haught RC,Kelty K, Blannon JC,Cmehil D.Impact on water distribution system biofilm densites from RO membrane treatment of supply water. J Environ Eng Sci. 2007;6(10):449-54.

41. Reasoner DJ, Blannon JC, Geldreich EE. Microbiological characteristics of third -faucet Point of Use devices. J Am Water Works Assoc. 1999; 82(6):6-9.

42. Rompre A, Servais P, Baudart J, Roubin M, Laurent P. Detection and enumeration of coliforms in drinking water: current methods and emerging approaches. J Microbiol methods. 2002; 49:31-54. 